\title{
Dividends as a Solution to Agency Cost and Opaqueness: Theory and Evidence
}

\author{
Brandon C. L. Morris ${ }^{1} \&$ Brian S. Roseman ${ }^{2}$ \\ ${ }^{1}$ Raj Soin School of Business, Wright State University, Dayton, OH, USA \\ ${ }^{2}$ School of Business Administration, University of Mississippi, Oxford, MS, USA \\ Correspondence: Brian S. Roseman, School of Business Administration, University of Mississippi, 253 Holman \\ Hall North, Oxford, MS 38677, USA. Tel: 662-915-5820. E-mail: broseman@bus.olemiss.edu
}

Received: November 6, 2014

Accepted: November 19, 2014

Online Published: December 25, 2014

doi:10.5539/ijef.v7n1p24

URL: http://dx.doi.org/10.5539/ijef.v7n1p24

\begin{abstract}
We develop a model that explains the use of dividends in continuous time as a means of reducing agency cost. Ideally firms are transparent and shareholders can costlessly monitor managers. However perfect transparency is not always possible. Managers of opaque firms are harder to monitor and are subject to greater agency costs than managers of firms that are transparent. Similar to previous models, dividends are a means of reducing agency cost by removing excess cash available to managers. Since shareholders can monitor firms that are transparent, dividends are only required for opaque firms. Dividend policy is reevaluated whenever shifts in opaqueness occur. This reevaluation provides a multiperiod explanation to dividends that is absent in prior literature. Our theory generates predictions that are tested and supported.
\end{abstract}

Keywords: dividends, agency costs, transparency, dividend policy

\section{Introduction}

There are three important questions related to dividend policy theories; (1) Why do firms pay dividends? (2) Once a dividend policy is set, is there a need to reevaluate? (3) Is there a reason firms will suspend a dividend once it is implemented. There are numerous theories that answer the first question. The latter two questions, while empirically tested, have not gained much attention in theoretical work. In this paper we present a model to address these questions and also provide empirical support.

Our model explains dividends in continuous time as a means of reducing agency cost. If shareholders can costlessly monitor managers then there is no need for other mechanisms to control for agency costs. The cost of monitoring positively associated with the level of opaqueness, that is, agency costs are easier to control in transparent firms while opaque are thus subject to greater agency costs. However, opacity is not stochastic, in each period the opaqueness of a firm can shift along with agency costs. We show that as firm opacity shifts, firm dividend policy also shifts to control for new levels of agency cost.

The main contribution of this paper is a multi-period explanation for dividend policy. The model presented here shows the need for firms to continuously update their dividend policy to avoid possible added agency costs. We also include an empirical section that provides support for the predictions of the model. The results suggest that firms pay dividends because of higher opacity. The univariate results show that firms that do pay dividends have higher opaqueness. The logit regression shows that higher opaqueness increases the likelihood of paying a dividend. These results holds for multiple different measures of opacity. There is also some evidence that dividend policy changes are the result of a change in firm opaqueness.

There are numerous theories on dividends. Easterbrook (1984) reviews the problems with signaling and catering theories of dividends and presents a new theory based on agency costs. Dividends are costly, so there must be a reason for firms to pay them. Signaling is possible, but the signal could be good or bad depending on whether the firm is signaling good times, or bad times by liquidating through dividends. Easterbrook suggests that controlling agency cost is a logical explanation for the use of dividends. In this paper we follow a similar argument that dividends can control for agency cost. However, as it stands, the agency cost explanation is not complete. Anecdotal evidence shows that dividend policy does change. Although changes are infrequent, it is not uncommon. How can the agency cost explanation presented in extant literature and changing dividend policies 
reconcile?

Some existing theories suggest dividends are used as a signal for earnings prospects in an economy with imperfect information. Bhattacharya (1979), Miller and Rock (1985) and John and Williams (1985) propose theories that suggest dividends are used to signal expected cash flows in imperfect markets. Dividends are associated with positive future earnings since low-type firms cannot afford to offer this signal. Easterbrook (1984) argues that dividends as signals are not practical. There are cheaper and more convenient forms of signaling. Easterbrook offers the idea that dividends are a form of monitoring in a world where managers are not perfect agents for shareholders. Owners that recognize this agency conflict require managers to distribute excess cash in the form of a dividend. Jensen (1986) and Lang and Litzenberger (1989) also suggest that potential waste by managers will be reduced by eliminating excess free cash flow. These theories highlight that dividends are not a financial decision, as Miller and Modigliani (1961) show that dividends are financially irrelevant in that they cannot change the value of a firm.

The current dividend models do not address why dividends may stop. Although some models are multi-period, they do not constantly evaluate why a firm will begin issuing dividends, or suppress dividends that are already in place. That is, there is no theoretical motivation on why dividend policy should change once it is set. One area that our model improves upon prior literature is the need for a multi-period model. It is a known empirical result that dividends are not constant. Firms may halt dividends and resume dividends. Dividends being desired for different states of the economy is not a unique contribution we make. Fuller and Goldstein (2011) show that dividends matter more in declining markets. Our model follows a similar argument. Although we do not look at declining markets, the argument we present is that dividends are more important for opaque firms. As will be shown in the next section, our model shows that the monitoring need of firms varies through time periods depending on the opaqueness of the managers efforts.

The remainder of this paper is as follows. The section 2 presents a simple multiperiod model for dividends. Section 3 describe the data and setup of the empirical section. We report the empirical results in Section 4, and conclude with Section 5.

\section{Model}

In this section we present an economic model, with firms that experience owner-manager agency cost. We model firm-level agency cost as a function of how opaque the firm is to its shareholders, where high opaqueness creates higher agency costs compared to a similar firm with low opaqueness. When opacity is low, owners are able to easily monitor managers and control perquisite spending, and when opacity is high, it is more difficult to monitor management's perquisite spending. During periods of high opaqueness an alternative to monitoring must be used to lower agency cost. We suggests that dividends are a good alternative to monitoring high opaque firms. Paying dividends reduces free cash flow, thus limiting the managers opportunity set to consume private benefits at the expense of the shareholders (Jensen, 1986).

Because managers are self-interested agents, we assume that they prefer high levels of opacity, therefore in every period the opaqueness of the firm will drift towards higher opacity levels. Agency costs are reduced by monitoring activities, as well as removing excess cash through dividends. Previous papers address dividends as a way to reduce agency costs. Easterbrook (1984) argues the existence of agency cost is a rational argument for paying dividends. Management misuse of free cash flow is costly to the firm. Dividends can reduce this free cash flow available to managers. In addition to dividends, debt is also a tool improve monitoring flow (Jensen, 1986).

Our model addresses three questions. First, why do firms begin paying dividends? Second, is there ever a need to reconsider the dividend policy once the firm sets it? And third, why do firms stop paying dividends? Prior studies ignore the latter two relevant questions; our model attempts to address the above three questions in a multi-period setting.

\subsection{Agency Cost and Opaqueness}

Owners evaluate the expected agency cost of the firm in each period of the economy. Transparency increases the owner's ability to effectively monitor the firm, while opaqueness makes it difficult to monitor the firm. Opaqueness, $\Omega$, is determined by exogenous and endogenous shocks. If a firm is opaque, the expected agency cost is high. If the firm is transparent, the expected agency cost is low.

Agency costs are a problem when the owner cannot monitor or observe the activities of the manager. When opacity is low, the owners will stop their efforts to further reduce agency costs. However, when opacity is high, the owner will begin to actively manage agency costs by reducing the free cash flows available to managers. A unique aspect of our model is that the sources of agency cost (i.e., free cash flow) are problems only when 
opaqueness is high. If the owner can observe the manager's actions, then the manager will not consume value-reducing perquisites. Therefore, the agency cost of a firm is a positive function of opaqueness. Absent of any policies required by the owner,

$$
\text { Agency cost }=A=f(\text { opaqueness })=\left\{\begin{array}{l}
A^{+} \text {if opaqueness is high }\left(\Omega^{+}\right) \\
A^{-} \text {of opaqueness is low }\left(\Omega^{-}\right)
\end{array}\right.
$$

A young firm is typically transparent. The transparency results from the IPO process and subsequent equity offerings. Growth prospects and new products are observable to owners. Early life cycle transparency does not necessitate the owner to reduce agency costs by requiring a dividend. As the firm matures, activities that previously provided transparency are not as frequent such as security issuances. Empirically DeAngelo, DeAngelo and Stulz (2010) support this claim, they show that growth and non-dividend paying firms comprise the majority of seasoned equity offerings. In the absence of shocks or transparency related activities, a firm becomes opaque.

Models that do not address opaqueness suggest that once the agency cost is handled (i.e. a dividend is implemented), the decision does not need to be evaluated again. Our model introduces shocks to opaqueness that create an incentive for owners to evaluate dividend policy. Every period in the model the opaqueness can shift. If a shift occurs, then agency costs also shift in the same direction. Owners therefore react to the changing levels agency costs and then adjusts the dividend policy accordingly.

Shocks disrupt an otherwise smooth opaqueness function $\Omega$. The firm has internal and external shocks that increase or decrease transparency. Examples of internal shocks that change opaqueness include new management, new product opportunities, or financial distress. Although these shocks can be positive or negative for firm value, they all will decrease opacity. External shocks include legal issues, natural disasters, or competition. In the absence of the shocks discussed, a firm will drift towards becoming more opaque.

$$
\text { Opaqueness }=\Omega=\text { (internal shocks, external shocks, drift) }
$$

Whether a shock increases or decreases value is not what drives the dividend policy change, it is the shock's effect on opaqueness that triggers a change in the expected agency cost than owners are exposed to. A key implication of our model is that the level of the firm opacity influences subsequent changes in dividend policy.

\subsection{The Model in Continuous Time}

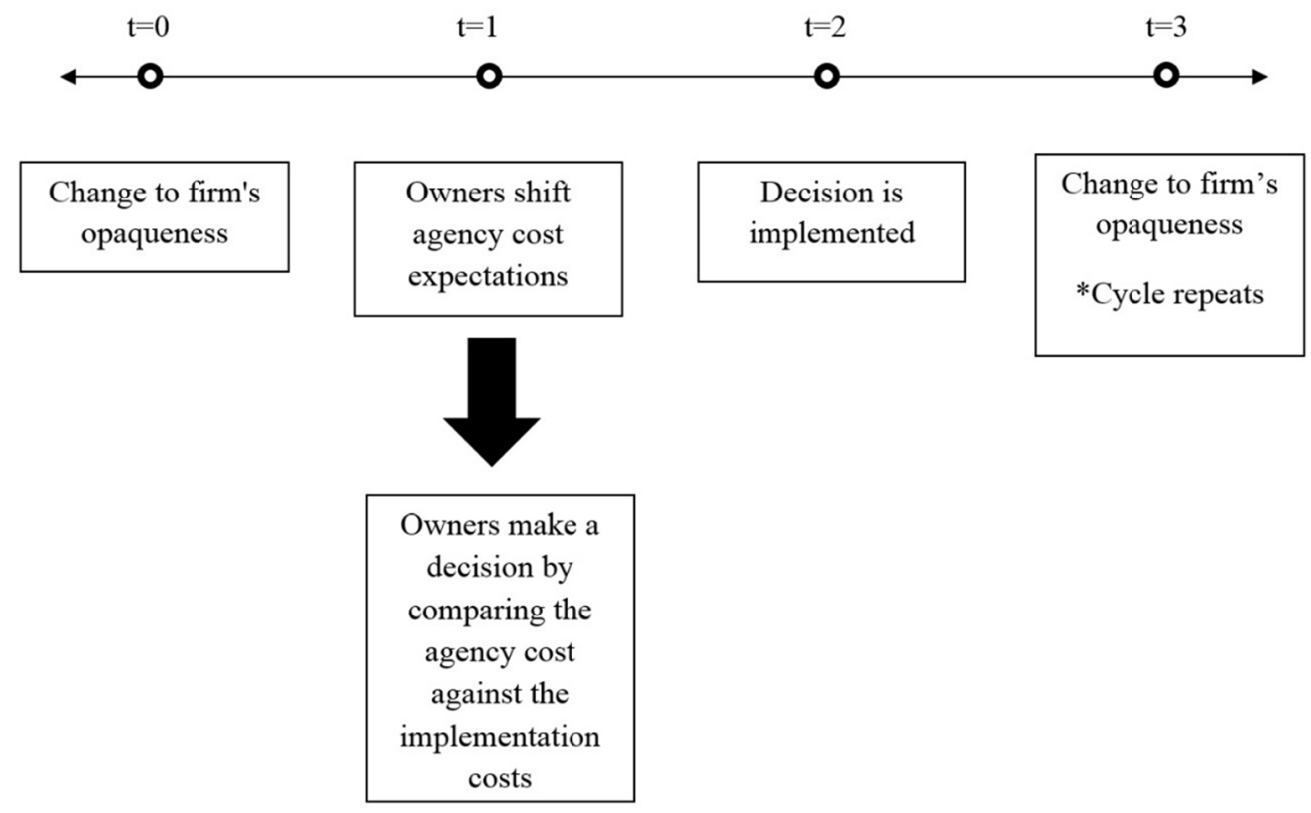

Figure 1. Opaqueness cycle

Figure 1 illustrates the decision process that accompanies a change in opacity. There are four points in each period. At the beginning of a period, the firm experiences a shock that affects opaqueness. Some examples of 
shocks given in the previous section include change in management, a potential law suit, or a high profile public event (employee strikes, oil spills, charitable donations). Naturally these shocks will change the firm's transparency. The owners will then observe the shock and calculate the expected agency cost, and compare that against the cost to implement a dividend. If the cost to implement a dividend is higher than the reduced agency cost, then the owner will not require a dividend. Alternatively, if the implementation cost is lower than the reduction in the agency cost, a dividend will be required. The decision is carried out, and the cycle repeats.

As a consequence of the implementation costs of a dividend, the owners are exposed to a tradeoff between agency costs and transaction costs. For convenience all costs that are not an agency cost are labeled transaction costs. As expressed previously, more opaque firms have higher agency costs. In addition to agency costs, transaction costs are also a factor in the owner's profits. These total owners costs are those related to not actively monitoring managers (the agency costs), and costs from actively monitoring managers (transaction costs).

Given the assumptions, the owner minimizes

$$
T C=A+C
$$

Where $T C, A$, and $C$ represent total cost, agency cost, and transaction cost respectively. The expected total cost is

$$
E(T C)=E(A)+E(C)
$$

Two cases are considered. First consider the case of when opaqueness is low. The expected total costs without a dividend are given by

$$
E\left(T C \mid \Omega^{-}, \text {no_div }\right)=A^{-}+E\left(C \mid \Omega^{-}, n o \_d i v\right)=A^{-}
$$

since there will be no transaction costs if a dividend is not implemented. The expected total costs with a dividend are given by

$$
E\left(T C \mid \Omega^{-}, \text {div }\right)=A_{d}^{-}+E(C)
$$

where $A_{d}{ }^{-}$is the agency cost with a dividend for a firm with low opaqueness. The owner will require a dividend if the following inequality holds:

$$
A_{d}^{-}+E(C)<A^{-}
$$

Because this inequality does not hold, we gain our first implication:

Implication 1a: Firms with low opaqueness will not pay a dividend.

The proof is easy to see. Owners can effectively monitor when opacity is low. A dividend will only reduce agency cost marginally, if at all. Agency cost with a dividend is no less than agency cost without a dividend when that opacity is low. Given the two agency costs will be equal,

$$
A_{d}{ }^{-}=A^{-}
$$

the difference between agency cost with and without a dividend will be zero. This leaves,

$$
E(C)<0
$$

which is clearly false.

The second case is when opaqueness is high. The expected total cost without a dividend is given by

$$
E\left(T C \mid \Omega^{+}, \text {no_div }\right)=A^{+}+E\left(C \mid \Omega^{+}, n o \_d i v\right)=A^{+}
$$

adding a dividend the expected total cost becomes

$$
E\left(T C \mid \Omega^{+} \text {, div }\right)=A_{d}^{+}+E(C)
$$

Similar to the low opaqueness scenario, the owner requires a dividend if the following inequality holds:

$$
A_{d}^{+}+E(C)<A^{+}
$$

Rearranging the terms in (9) yields

$$
E(C)<A^{+}-A^{-}
$$

where the right hand side of the inequality is the additional agency cost that an owner will experience if a dividend is not implemented. When this holds, the dividend will be paid. This yields the high opacity form of our first implication.

\section{Implication 1b: Firms with high opaqueness will pay a dividend.}

These results answer the initial question proposed earlier, why do firms start paying dividends? We see that when the cheaper form of controlling agency cost, monitoring, is not feasible, owners will rely on dividends. This also 
leads to other interesting questions: When the dividend policy is set in place, is there a need to reevaluate of adjust the policy? If owners do require a dividend, is there any instance that they would desire the suspension of the dividend? The model above motivates the benefit of studying dividends in a multiperiod setting.

We propose that opaqueness can change in any period. Consider a dividend paying firm that experiences a shock which alters the firm's opaqueness. If the shock decreases the opacity, and the firm becomes more transparent, the owners might be able control agency costs without the need of further dividends. When a firm is transparent, monitoring is as effective as dividends at reducing agency costs. The owners, in an effort to minimize their costs will suspend a dividend due to transaction costs. This is the second implication of the model:

\section{Implication 2: When a firm becomes transparent (opaque) owners will suspend (implement) a dividend.}

It has been argued that owners benefit when agency costs are low (Jensen, 1986). When firms are transparent, owners effectively monitor the managers, and do not require a dividend to lower the agency cost. However, when then opacity is high, the owner is not able to monitor management. The owner will remove excess free cash flow through dividends when opaqueness is high. When opaqueness is low owners will not pay a dividend, or suspend a dividend if already in place. These implications can be empirically tested. In the next section, we describe the data and the methodology of the empirical tests. The results will follow.

\section{Data and Variables}

Data is collected from Compustat, IBES, and CRSP for the period 1993-2010. Compustat includes the list of all dividend paying firms, as well as items that will be used to create opacity measures. IBES and CRSP will also be used to generate additional opacity measures. Firms that do not have total assets or stock prices are removed. Additionally, the sample only includes U.S. firms listed on the NYSE, AMEX and Nasdaq exchange. Regulated industries including finance firms and utilities are removed along with firms with negative book values. The fifth opacity measure, described later, requires four consecutive years of data, therefore, firms with less than four years of data are necessarily eliminated. These filters leave 4,935 unique firms across the sample period and 36,494 firm year observations.

Table 1. Assumptions and variable definitions

\begin{tabular}{|c|c|}
\hline \multicolumn{2}{|r|}{ Panel A: Model Assumptions } \\
\hline Assumption 1 & Firms in each period of the economy are subject to opacity shocks. \\
\hline Assumption 2 & Agency cost is a positive function of opaqueness. \\
\hline Assumption 3 & Dividends do not reduce agency when there is costless monitoring \\
\hline \multicolumn{2}{|r|}{ Panel B: Variable Definitions } \\
\hline Variable & Definition \\
\hline Dividend Payers & Dummy variable equal to one for the year that a firm pays a dividend \\
\hline Divyield & Dividend per share divided by the price per share. Zero otherwise \\
\hline Opacity1 & One divided by the number of analysts \\
\hline Opacity2 & The standard deviation of analyst forecasts for earnings per share \\
\hline Opacity3 & The difference between mean analyst forecast and actual earnings per share \\
\hline Opacity4 & $\begin{array}{l}\text { For all observations each year, the average bid/ask spread, average volume of shares traded, inverse number of } \\
\text { analysts, and analyst forecast error are ranked into percentiles. The percentiles are then added and divided by } 4 \text {. } \\
\text { The result is a variable between } 1 \text { and } 99 \text { indicating the percentile of opacity. }\end{array}$ \\
\hline Opacity 5 & $\begin{array}{l}\text { Following Lang et al. (2012), Opacity5 is a proxy for earnings management. Managers are able to smooth } \\
\text { earnings using accruals. This smoothing is indicative of higher opacity. See Lang et al (2012) Appendix A for a } \\
\text { description of the calculation. }\end{array}$ \\
\hline Size & $\begin{array}{l}\text { With the exception of summary statistics, Size is the percent of firms with smaller market cap each year. This is } \\
\text { similar to Fama, French (2012) that helps control for time effects of size. }\end{array}$ \\
\hline Profit & Total earnings divided by total assets \\
\hline Growth & Percentage change in assets from year $t-1$ to year $t$ \\
\hline Investment & Ratio of market value of equity to book value of equity \\
\hline Leverage & Total debt divided by total assets \\
\hline
\end{tabular}

Note. Assumptions from the theoretical model are presented in Panel A. Variables used in the statistical tests are reported in Panel B. Following Fama, French (2002) the control variables include a measure for Size, Profit, Growth, and investment. All variables are measured annually. 
Our theoretical model assumes that dividends are partly determined by firm opacity. Our measure for dividends is a dummy variable equal to one if a firm pays a dividend, zero otherwise. Following Fama and French (2001) standard controls for dividends and the dividend yield include a measure of size, profitability, firm growth, and investment opportunities. Fama and French (2001) and Dennis and Osobov (2008) note that firm size needs special consideration for comparability across time. To account for this we follow a similar method, size of a firm is the percentage of firms with a smaller market cap in the same year. Profitability is measured by earnings over assets. Growth is calculated as the percentage change in assets. Investment is measured as the ratio of market value of equity to the book value of equity. A summary of the variables used are presented in Panel B of Table 1.

The measure of a firm's opaqueness is difficult to compute. Because there are no direct measures of opacity, prior studies use several proxies. We use three standard measures of opacity, as well as two robust methods. All of the opacity measure are transformed so that higher numbers in the variable indicate greater opacity. The first measure of opacity is Opacityl, the inverse of the number of analysts. The greater number of analysts that cover a firm could lead to higher transparency. The second measure, Opacity2, is the diversity of analyst estimates, measured as the standard deviation of analyst forecasts. Lang et al. (2012) use the error of analyst estimates as a measure for opacity, which we use as our third measure, Opacity3. It is measured as the mean analyst estimate minus the actual earnings per share, squared.

The fourth variable used to measure opacity is an index proposed by Anderson et al. (2009). We use the average percentile rank score of trading volume, bid/ask spread, number of analysts, and analyst error for each firm. Opacity4 range is between 1 and 100. Anderson et al. describe their measure as "a relative robust measure of opaqueness because it averages across multiple measures and includes inputs from market trades and analyst coverage."

The final proxy for opacity, Opacity5, is the extent to which a firm engages in discretionary earnings management. Managers are able to use accruals to smooth out earnings. This earnings smoothing is an indicator of transparency since outsiders are unable to see the actual events and earnings a company reports. To measure discretionary (excess) earnings management, we use the method proposed by Lang et al. (2012). Lang et al. discretionary smoothness begins by computing two standard measures of earnings smoothness. SMTH1 is measured as the standard deviation of net income divided by the standard deviation of cash flow from operations over the past 5 years. SMTH2 is the correlation between cash flow from operations and total accruals. Next residuals are obtained by regressing $S M T H 1$ and $S M T H 2$ by known determinants of earnings smoothness using the following regression:

$$
\begin{aligned}
& \text { SMTH }_{t} \text { or SMTH } 2_{t}=\beta_{1} \text { LNASSETS }_{t}+\beta_{2} L E V_{t}+\beta_{3} \text { BM }_{t}+\beta_{4} \text { STD }_{\text {SALES }_{t}}+\beta_{5} \% \text { LOSS }_{t} \\
& \quad+\beta_{6} \text { OPCYCLE } \\
& +
\end{aligned}
$$

Where LNASSETS is the natural log of assets, LEV is firm leverage, BM is the book-to-market ratio, $S T D_{\text {SALESt }}$ is the standard deviation of sales, $\% L O S S_{t}$ is the percentage of years the firm experienced losses over the last five years, $O P C Y C L E_{t}$ is the firm's operating cycle which is computed as the log of days receivables outstanding plus inventories, $S G_{t}$ is the firm's 2-year sales growth, $O P L E V_{t}$ is a capital intensity measure computed as the percentage of fixed assets, and $A V E C F O_{t}$ captures average cash flow from operations scaled by assets. Year and industry fixed effects are also added to the model. The residuals from the above model are ranked by percentile and averaged together to create the final discretionary smoothness measure, DIS_SMTHC. This measure is the excess smoothing that manager's control. Lang et al. acknowledge that there are fundamental reasons to smooth earnings, and the measure DIS SMTHC is what is remaining after controlling for the fundamental reasons. This final measure is fundamentally different than the four previous measures that are based more on trading characteristics and analyst activity.

\subsection{Descriptive Statistics}

Table 2 summarizes all the variables used in our analysis. Just over $36 \%$ of the firms pay a dividend at some point during the sample period, with an average dividend yield of $1 \%$. We use five proxies for opacity. The first three are relatively simple including the inverse of the number of analysts, the dispersion of analyst forecasts, and analyst error. The fourth measure is an index of opacity variables, developed by Anderson et al. (2009). The fifth measure of opacity is a measure of discretionary earnings management proposed by Lang et al. (2012). The sample of firms is skewed by large firms where the mean (median) firm has total assets of 3.3 billion (343 Million). Panels B and C in Table 2 show that some of our opacity proxies have remained stable over time, while others have shifted higher. Specifically, during the sample period Opacity 1 decreased by 13\%, Opacity 2 increased by $32 \%$, Opacity 3 increased by $57 \%$, Opacity 4 decreased by $27 \%$, and Opacity 5 increased by a 
marginal $4 \%$.

Table 2. Summary statistics

\begin{tabular}{|c|c|c|c|c|c|c|}
\hline & $\begin{array}{l}\mathrm{N} \\
{[1]} \\
\end{array}$ & $\begin{array}{l}\text { Mean } \\
{[2]}\end{array}$ & $\begin{array}{l}\text { Median } \\
{[3]}\end{array}$ & $\begin{array}{l}\text { Min } \\
{[4]} \\
\end{array}$ & $\begin{array}{l}\text { Max } \\
{[5]}\end{array}$ & $\begin{array}{l}\text { Std Dev } \\
{[6]}\end{array}$ \\
\hline \multicolumn{7}{|c|}{ Panel A: Full Sample } \\
\hline Dividend Payers & 4731 & 0.363 & 0.000 & 0.000 & 1.000 & 0.438 \\
\hline Divyield & 4731 & 0.010 & 0.000 & 0.000 & 3.344 & 0.069 \\
\hline Opacityl & 3790 & 0.343 & 0.230 & 0.022 & 1.000 & 0.290 \\
\hline Opacity 2 & 3756 & 0.528 & 0.381 & 0.000 & 79.161 & 1.502 \\
\hline Opacity3 & 3790 & 2.497 & 0.022 & 0.000 & 5177.360 & 97.624 \\
\hline Opacity4 & 3772 & 46.368 & 45.750 & 3.000 & 94.000 & 17.015 \\
\hline Opacity 5 & 4731 & 51.441 & 50.321 & 0.750 & 99.000 & 19.913 \\
\hline Size (Total Assets) & 4731 & $3,292.400$ & 343.447 & 0.611 & $766,517.000$ & $17,755.410$ \\
\hline Profit & 4298 & 0.137 & 0.127 & 0.000 & 3.415 & 0.085 \\
\hline Growth & 4297 & 0.417 & 0.190 & 0.001 & 188.395 & 3.218 \\
\hline Investment & 4731 & 0.683 & 0.544 & 0.001 & 31.478 & 0.891 \\
\hline Leverage & 4725 & 0.157 & 0.115 & 0.000 & 0.879 & 0.159 \\
\hline \multicolumn{7}{|c|}{ Panel B: 1997-2002 } \\
\hline Dividend Payers & 3492 & 0.390 & 0.000 & 0.000 & 1.000 & 0.463 \\
\hline Divyield & 3492 & 0.008 & 0.000 & 0.000 & 0.586 & 0.024 \\
\hline Opacityl & 2454 & 0.363 & 0.250 & 0.027 & 1.000 & 0.302 \\
\hline Opacity 2 & 2424 & 0.431 & 0.344 & 0.000 & 25.043 & 0.629 \\
\hline Opacity3 & 2454 & 1.389 & 0.016 & 0.000 & 3041.520 & 61.419 \\
\hline Opacity4 & 2444 & 54.192 & 55.000 & 2.000 & 94.000 & 15.571 \\
\hline Opacity 5 & 3492 & 49.915 & 48.750 & 0.750 & 99.000 & 20.403 \\
\hline Size (Total Assets) & 3492 & $2,356.430$ & 268.879 & 1.422 & $273,865.330$ & $10,241.110$ \\
\hline Profit & 3181 & 0.142 & 0.134 & 0.002 & 0.697 & 0.070 \\
\hline Growth & 3077 & 0.471 & 0.185 & 0.000 & 188.395 & 3.743 \\
\hline Investment & 3492 & 0.762 & 0.556 & 0.001 & 38.441 & 1.168 \\
\hline Leverage & 3485 & 0.168 & 0.132 & 0.000 & 0.879 & 0.161 \\
\hline \multicolumn{7}{|c|}{ Panel C: 2003-2007 } \\
\hline Dividend Payers & 3664 & 0.368 & 0.000 & 0.000 & 1.000 & 0.450 \\
\hline Divyield & 3664 & 0.011 & 0.000 & 0.000 & 3.344 & 0.078 \\
\hline Opacityl & 2895 & 0.311 & 0.190 & 0.022 & 1.000 & 0.286 \\
\hline Opacity 2 & 2880 & 0.578 & 0.400 & 0.005 & 79.161 & 1.655 \\
\hline Opacity3 & 2895 & 2.177 & 0.018 & 0.000 & 5177.360 & 96.373 \\
\hline Opacity4 & 2880 & 39.438 & 38.000 & 3.000 & 94.000 & 15.953 \\
\hline Opacity5 & 3664 & 52.059 & 52.000 & 1.333 & 99.000 & 21.884 \\
\hline Size (Total Assets) & 3664 & $4,304.430$ & 446.120 & 0.611 & $766,517.000$ & $21,490.990$ \\
\hline Profit & 3325 & 0.133 & 0.121 & 0.000 & 3.415 & 0.092 \\
\hline Growth & 3346 & 0.306 & 0.161 & 0.000 & 66.750 & 1.335 \\
\hline Investment & 3664 & 0.613 & 0.514 & 0.009 & 6.762 & 0.469 \\
\hline Leverage & 3660 & 0.145 & 0.099 & 0.000 & 0.836 & 0.157 \\
\hline
\end{tabular}

Note. The summary statistics of all firms on the NYSE, Nasdaq and Amex exchange. Utility and financial firms, as well as firms that do not have a minimum of four consecutive years of data. All opacity measures are constructed so that higher values indicate more opacity. The variable definitions with the exception of Size are as reported in Table 1. Size in this table is reported as total assets in millions.

To better understand how our proxies for the opacity measures we measure their correlations. Table 3 shows that other than measures that use analysts as part of the measurement (Opacity 1 and Opacity 2), there is little correlation. Of interest is the correlation between the fourth and fifth measures of opacity. Both of these are designed to be relatively robust, but have little correlation with each other. This low correlation strengthens the justification for using multiple measures of opacity as each can represent different aspects of firm opacity. 
Table 3. Variable correlation matrix

\begin{tabular}{|c|c|c|c|c|c|c|c|c|c|c|}
\hline & Opacity1 & Opacity2 & Opacity3 & Opacity4 & Opacity 5 & Size & Profit & Growth & Invest & Lev \\
\hline Opacity1 & 1 & & & & & & & & & \\
\hline Opacity2 & $\begin{array}{l}-0.116^{* *} \\
(<.0001)\end{array}$ & 1 & & & & & & & & \\
\hline Opacity3 & $\begin{array}{c}0.011 \\
(0.0988)\end{array}$ & $\begin{array}{c}0.532 \\
(<.0001)\end{array}$ & 1 & & & & & & & \\
\hline Opacity4 & $\begin{array}{c}0.689 \\
(<.0001)\end{array}$ & $\begin{array}{l}-0.005 \\
(0.4132)\end{array}$ & $\begin{array}{c}0.026 \\
(<.0001)\end{array}$ & 1 & & & & & & \\
\hline Opacity 5 & $\begin{array}{c}0.032 \\
(<.0001)\end{array}$ & $\begin{array}{l}-0.027 \\
(<.0001)\end{array}$ & $\begin{array}{c}0.011 \\
(0.0955)\end{array}$ & $\begin{array}{c}0.013 \\
(0.0565\end{array}$ & 1 & & & & & \\
\hline Size & $\begin{array}{l}-0.553 \\
(<.0001)\end{array}$ & $\begin{array}{c}0.216 \\
(<.0001)\end{array}$ & $\begin{array}{l}-0.006 \\
(0.402)\end{array}$ & $\begin{array}{l}-0.451 \\
(<.0001)\end{array}$ & $\begin{array}{l}-0.055 \\
(<.0001\end{array}$ & 1 & & & & \\
\hline Profit & $\begin{array}{l}-0.094 \\
(<.0001)\end{array}$ & $\begin{array}{c}0.079 \\
(<.0001)\end{array}$ & $\begin{array}{l}-0.014 \\
(0.0493)\end{array}$ & $\begin{array}{l}-0.088 \\
(<.0001)\end{array}$ & $\begin{array}{l}-0.060 \\
(<.0001)\end{array}$ & $\begin{array}{c}0.059 \\
(<.0001)\end{array}$ & 1 & & & \\
\hline Growth & $\begin{array}{l}-0.007 \\
(0.366)\end{array}$ & $\begin{array}{l}-0.004 \\
(0.6089)\end{array}$ & $\begin{array}{l}-0.001 \\
(0.8744)\end{array}$ & $\begin{array}{c}0.003 \\
(0.7227)\end{array}$ & $\begin{array}{c}0.002 \\
(0.7758)\end{array}$ & $\begin{array}{c}0.001 \\
(0.8504)\end{array}$ & $\begin{array}{l}-0.041 \\
(<.0001)\end{array}$ & 1 & & \\
\hline Investment & $\begin{array}{c}0.220 \\
(<.0001)\end{array}$ & $\begin{array}{l}-0.002 \\
(0.8076)\end{array}$ & $\begin{array}{c}0.012 \\
(0.065)\end{array}$ & $\begin{array}{c}0.267 \\
(<.0001)\end{array}$ & $\begin{array}{c}0.007 \\
(0.2261)\end{array}$ & $\begin{array}{l}-0.068 \\
(<.0001)\end{array}$ & $\begin{array}{l}-0.154 \\
(<.0001)\end{array}$ & $\begin{array}{l}-0.021 \\
(0.0016)\end{array}$ & 1 & \\
\hline Leverage & $\begin{array}{l}-0.116 \\
(<.0001)\end{array}$ & $\begin{array}{c}0.077 \\
(<.0001)\end{array}$ & $\begin{array}{l}-0.002 \\
(0.7625)\end{array}$ & $\begin{array}{c}0.016 \\
(0.0183)\end{array}$ & $\begin{array}{l}-0.015 \\
(0.0056)\end{array}$ & $\begin{array}{c}0.370 \\
(<.0001)\end{array}$ & $\begin{array}{l}-0.100 \\
(<.0001)\end{array}$ & $\begin{array}{c}0.016 \\
(0.0179)\end{array}$ & $\begin{array}{c}0.037 \\
(<.0001)\end{array}$ & 1 \\
\hline
\end{tabular}

\section{Empirical Results}

In this section we test the implications of our theoretical model. The main implications from our model include the prediction that firms that have high opacity will be required to pay a dividend. Also our model suggests that dividend policy changes are the result of changes in opacity.

\subsection{Dividends and Opaqueness}

In our first analysis, we test the difference in opacity between dividend payers and non-dividend payers using a matched-sample technique. Table 4 presents the results. For reference, Panel A displays the opacity levels of all firms. Panel B reports opacity measures for dividend payers, and Panel C for non-dividend payers. Panel D is where we repot the different and statistical significance in opacity between the two groups for all five of our proxies.

Table 4. Differences in opacity

\begin{tabular}{|c|c|c|c|c|c|c|c|c|c|}
\hline & \multicolumn{3}{|c|}{ 1997-2010 } & \multicolumn{3}{|c|}{ 1997-2002 } & \multicolumn{3}{|c|}{$2003-2010$} \\
\hline & Mean & Median & $\mathrm{n}$ & Mean & Median & $\mathrm{n}$ & Mean & Median & $\mathrm{N}$ \\
\hline \multicolumn{10}{|c|}{ Panel A: All Firms } \\
\hline Opacityl & 0.295 & 0.181 & 6,807 & 0.333 & 0.218 & 2,529 & 0.2660 & 0.1627 & 3,915 \\
\hline Opacity2 & 0.528 & 0.398 & 6,765 & 0.438 & 0.363 & 2,505 & 0.6202 & 0.4404 & 3,903 \\
\hline Opacity3 & 0.626 & 0.006 & 6,807 & 1.286 & 0.005 & 2,529 & 0.2874 & 0.0069 & 3,915 \\
\hline Opacity4 & 44.103 & 43.000 & 6,785 & 53.863 & 54.000 & 2,517 & 37.8443 & 37.0000 & 3,905 \\
\hline Opacity 5 & 49.812 & 51.000 & 9,394 & 47.791 & 47.250 & 3,772 & 50.7291 & 54.0000 & 5,130 \\
\hline \multicolumn{10}{|c|}{ Panel B : Dividend Payers } \\
\hline Opacityl & 0.335 & 0.217 & 3,279 & 0.374 & 0.255 & 1,205 & 0.3020 & 0.1920 & 1,896 \\
\hline Opacity 2 & 0.576 & 0.458 & 3,251 & 0.473 & 0.406 & 1,188 & 0.6600 & 0.5250 & 1,890 \\
\hline Opacity3 & 0.195 & 0.007 & 3,279 & 0.068 & 0.005 & 1,205 & 0.3258 & 0.0085 & 1,896 \\
\hline Opacity4 & 47.780 & 48.000 & 3,268 & 57.732 & 58.000 & 1,196 & 41.1805 & 40.0000 & 1,895 \\
\hline Opacity 5 & 50.396 & 52.500 & 4,697 & 48.387 & 48.000 & 1,886 & 51.0214 & 55.0000 & 2,565 \\
\hline \multicolumn{10}{|c|}{ Panel C: Non-Payers } \\
\hline Opacityl & 0.257 & 0.157 & 3,528 & 0.295 & 0.189 & 1,324 & 0.2321 & 0.1404 & 2,019 \\
\hline Opacity 2 & 0.482 & 0.347 & 3,514 & 0.407 & 0.327 & 1,317 & 0.5828 & 0.3672 & 2,013 \\
\hline
\end{tabular}




\begin{tabular}{|c|c|c|c|c|c|c|c|c|c|}
\hline Opacity3 & 1.026 & 0.005 & 3,528 & 2.394 & 0.005 & 1,324 & 0.2513 & 0.0058 & 2,019 \\
\hline Opacity4 & 40.686 & 39.000 & 3,517 & 50.361 & 50.000 & 1,321 & 34.6990 & 33.0000 & 2,010 \\
\hline Opacity 5 & 49.228 & 49.500 & 4,697 & 47.195 & 46.500 & 1,886 & 50.4368 & 53.0000 & 2,565 \\
\hline \multicolumn{10}{|c|}{ Panel D: Difference in Opacity (Div. payer - nonpayer) } \\
\hline \multirow{2}{*}{ Opacityl } & $0.077 * * *$ & & & \multicolumn{2}{|c|}{$0.079 * * *$} & \multicolumn{2}{|r|}{$0.077 * * *$} & & \\
\hline & $(11.44)$ & & & \multicolumn{2}{|c|}{$(6.88)$} & \multicolumn{2}{|r|}{$(9.33)$} & & \\
\hline \multirow{2}{*}{ Opacity2 } & $0.094 * * *$ & & & \multicolumn{2}{|c|}{$0.065 * * *$} & \multicolumn{2}{|r|}{$0.109 * * *$} & & \\
\hline & $(3.84)$ & & & \multicolumn{2}{|c|}{$(2.53)$} & \multicolumn{2}{|r|}{$(3.04)$} & & \\
\hline \multirow{2}{*}{ Opacity3 } & -0.831 & & & \multicolumn{2}{|c|}{-2.326} & \multicolumn{2}{|r|}{0.065} & & \\
\hline & $(0.93)$ & & & \multicolumn{2}{|c|}{$(0.98)$} & \multicolumn{2}{|r|}{$(0.089)$} & & \\
\hline \multirow{2}{*}{ Opacity4 } & $7.095 * * *$ & & & \multicolumn{2}{|c|}{$7.371 * * *$} & \multicolumn{2}{|r|}{$7.171 * * *$} & & \\
\hline & $(16.81)$ & & & \multicolumn{2}{|c|}{$(12.06)$} & \multicolumn{2}{|r|}{$(14.76)$} & & \\
\hline \multirow{2}{*}{ Opacity 5} & $1.169 * * *$ & & & \multicolumn{2}{|c|}{1.191} & \multicolumn{2}{|r|}{1.153} & & \\
\hline & $(2.14)$ & & & \multicolumn{2}{|c|}{$(1.49)$} & \multicolumn{2}{|r|}{$(1.57)$} & & \\
\hline
\end{tabular}

Note. This table tests the differences in opacity for our sample. Panel A presents the opacity measures for all firms in our sample, Panel B displays opacity for dividend paying firms, and Panel C reports non-dividend paying firm opacity. Panel D reports the differences between dividend paying firms and non-dividend paying firms. T-statistics are reported in parentheses with ***, **, and * indicating significance at the $1 \%, 5 \%$ and $10 \%$ levels respectively.

As seen in Table 3, size and opacity are negatively correlated, where large firms are less opaque than small firms. As stated earlier, we use a matched sample to control for the potential bias based on firm size. Each dividend paying firm is matched with a non-dividend paying firm based on size and book to market ratio, with no duplicate matches allowed. The cross-sectional results in Panel D confirms the first implication of our model, that dividend paying firms have higher opaqueness than non-dividend paying firms. Opacity 3 is the only proxy that is insignificant throughout each time period. Both of our robust measures of opacity are significant. The index measure, Opacity 4, suggests dividend paying firms are about 7 percentile points higher in opaqueness than non-dividend paying firms and the discretionary smoothing measure, Opacity 5, suggests that dividend paying firms are about 1.15 percentiles more opaque than non-dividend paying firms on average, again consistent with the theoretical implication of our model.

Table 5 displays the results for the logit analysis. A dummy variable of one for dividend paying firms is the dependent variable. Following Fama and French (2001) we control for size, profitability, growth and investment prospects. In addition we separately include the five measures of opacity. Similar to Table 4, there is evidence that firms that have higher opaqueness are more likely to pay a dividend. Also like Table 4, the more robust measures of opacity, shown in columns 4 and 5, and are positive and significant. In conclusion, there is strong evidence in favor of the opaqueness hypothesis for paying dividends as an answer to agency cost.

Table 5. Logit regression (divpayers $=1$ )

\begin{tabular}{llllll}
\hline & {$[1]$} & {$[2]$} & {$[3]$} & {$[4]$} & {$[5]$} \\
\hline Intercept & $-2.8306^{* * *}$ & $-1.3205^{* * *}$ & $-1.3387^{* * *}$ & $-3.8271^{* * * *}$ & $-1.0625^{* * *}$ \\
& $(<.0001)$ & $(<.0001)$ & $(<.0001)$ & $(<.0001)$ & $(<.0001)$ \\
Control_size & $0.0257^{* * *}$ & $0.0084^{* * *}$ & $0.0089^{* * *}$ & $0.0261^{* * *}$ & $0.0027^{* * *}$ \\
& $(<.0001)$ & $(<.0001)$ & $(<.0001)$ & $(<.0001)$ & $(0.0174)$ \\
Control_profit & $4.5795^{* * *}$ & $4.1315^{* * *}$ & $4.2334^{* * *}$ & $3.9254^{* * *}$ & $4.0198^{* * *}$ \\
& $(<.0001)$ & $(<.0001)$ & $(<.0001)$ & $(<.0001)$ & $(<.0001)$ \\
Control_growth & $-0.2735^{* * *}$ & $-0.2978^{* * *}$ & $-0.3056^{* * *}$ & $-0.3589^{* * *}$ & $-0.2963^{* * *}$ \\
& $(<.0014)$ & $(<.0005)$ & $(<.0003)$ & $(<.0001)$ & $(<.0001)$ \\
Control_Investment & -0.0317 & $0.3326^{*}$ & $0.3679^{*}$ & $-0.5182^{* * *}$ & $0.4389^{* * *}$ \\
& $(0.8023)$ & $(0.0063)$ & $(0.0022)$ & $(<.0001)$ & $(0.0116)$ \\
Opacity1 & $2.4083^{* * *}$ & & & & \\
& $(<.0001)$ & & & & \\
Opacity2 & & 0.0671 & & & \\
& & $(0.1882)$ & & & \\
Opacity3 & & & -0.0078 & & \\
& & & $(0.7555)$ & & \\
\hline
\end{tabular}




\begin{tabular}{|c|c|c|c|c|c|}
\hline Opacity 4 & & & & $\begin{array}{l}0.0462 * * * \\
(<.0001)\end{array}$ & \\
\hline Opacity 5 & & & & & $\begin{array}{l}0.0037 * * * \\
(.0003)\end{array}$ \\
\hline$n$ & 4,773 & 4,750 & 4,773 & 4,757 & 6,336 \\
\hline
\end{tabular}

Note. The logit regression dependent variable is an indicator variable equal to 1 form dividend paying firms. Following Fama and French (2002) the controls include a variable for size (percent of firms in a given year with smaller market cap), profit (earnings over assets), growth (percentage change in assets), and investment (market to book ratio). The five variables of opacity are run in separate regressions. P-values are reported in parentheses with $* * *, * *$, and $*$ indicating significance at the $1 \%, 5 \%$ and $10 \%$ levels respectively.

\subsection{Investigating the Multiperiod Aspect of Dividends}

The most significant contribution of the model presented in section 2 is the explanation for why dividends are a multiperiod decision, and not a onetime choice. Our model suggests that owners will require a dividend if opacity increases, and suspend a dividend if opacity drops. To test this we look at dividend policy changes during the sample time period. Specifically we gather all instances of when a dividend paying firm suspends a dividend, and when a non-dividend paying firm begins paying a dividend. We find 747 observations of a dividend being implemented, and 675 cases of dividend suspensions. The multiperiod hypothesis suggests that opacity is low the year before a dividend implementation. Opacity should increase the year of implementation and the year after.

Table 6 displays the results for this test. Focusing on the robust measures, opacity decreases the year a dividend is implemented, and decreases even further the year following. This result is statistically significant for the index measure, and insignificant for the discretionary smoothing measure. Although this is not perfectly in line with the multiperiod hypothesis, the result is still of interest. When a firm implements a dividend, a fundamental change in opacity occurs. Comparing this result with those in the previous section might suggest that although dividend paying firms are not as transparent as non-dividend paying firms, there is a component of the dividend that decreases opacity.

Table 6. Dividend implementation

\begin{tabular}{|c|c|c|c|}
\hline & Mean & Median & $\mathrm{n}$ \\
\hline & {$[1]$} & [2] & {$[3]$} \\
\hline \multicolumn{4}{|c|}{ Panel A: Year prior to dividend implementation } \\
\hline Opacity 1 & 0.345 & 0.212 & 452 \\
\hline Opacity2 & 0.409 & 0.329 & 448 \\
\hline Opacity3 & 0.222 & 0.004 & 452 \\
\hline Opacity4 & 44.577 & 44.000 & 449 \\
\hline Opacity 5 & 50.134 & 49.500 & 747 \\
\hline \multicolumn{4}{|c|}{ Panel B: Dividend implemented } \\
\hline Opacityl & 0.343 & 0.200 & 468 \\
\hline Opacity2 & 0.446 & 0.344 & 454 \\
\hline Opacity3 & 0.117 & 0.005 & 468 \\
\hline Opacity4 & 42.916 & 42.000 & 463 \\
\hline Opacity 5 & 49.359 & 53.000 & 747 \\
\hline \multicolumn{4}{|c|}{ Panel C: Year after dividend implementation } \\
\hline Opacityl & 0.319 & 0.184 & 390 \\
\hline Opacity2 & 0.476 & 0.388 & 388 \\
\hline Opacity3 & 0.197 & 0.005 & 390 \\
\hline Opacity4 & 41.487 & 40.000 & 390 \\
\hline Opacity 5 & 48.619 & 51.000 & 628 \\
\hline \multicolumn{4}{|c|}{ Panel D: Difference between $\mathrm{t}-1$ and $\mathrm{t}+1$} \\
\hline \multirow[t]{2}{*}{ Opacity 1} & 0.0257 & & \\
\hline & $(1.16)$ & & \\
\hline \multirow[t]{2}{*}{ Opacity 2} & -0.0669 & & \\
\hline & $(2.62)$ & & \\
\hline Opacity3 & 0.0249 & & \\
\hline
\end{tabular}




\begin{tabular}{ll}
\hline & $(0.16)$ \\
Opacity4 & $3.0897^{* * *}$ \\
& $(2.38)$ \\
Opacity5 & 1.5152 \\
& $(1.00)$ \\
\hline
\end{tabular}

Note. This table reports the opacity around changes in dividend policy. Panel A reports the opacity the year before a dividend is implemented. Panel B displays the opacity the year of a dividend implementation, and Panel C is the opacity after a dividend implementation. Panel D reports the differences and t-statistics between the year prior and following a dividend implementation. T-statistics are reported in parentheses with $* * *, * *$, and * indicating significance at the $1 \%, 5 \%$ and $10 \%$ levels respectively.

To complete the test of the multiperiod aspect of the model we also look at dividend suspensions. Table 7 is analogous to Table 6. The theoretical model predicts that owners of a firm will evaluate the opaqueness of the firm, and if transparency is increasing, then the owners will suspend a dividend. This suggests that the year prior to the dividend should have the highest opacity, with the year of the suspension and the year following to be monotonically decreasing. The robust measures of opacity in Table 7 show exactly that. Moving from the year before the suspension in Panel A, to the year following in Panel C, opacity decreases. The index measure of opacity is statistically significant at the $1 \%$ level. This supports the multiperiod hypothesis that when a firm is sufficiently transparent, owners will no longer require a dividend to adjust for the potential agency cost of a firm.

Table 7. Dividend suspension

\begin{tabular}{|c|c|c|c|}
\hline & Mean & Median & $\mathrm{n}$ \\
\hline & {$[1]$} & {$[2]$} & [3] \\
\hline \multicolumn{4}{|c|}{ Panel A: Year prior to dividend suspension } \\
\hline Opacityl & 0.350 & 0.230 & 380 \\
\hline Opacity 2 & 0.461 & 0.360 & 372 \\
\hline Opacity3 & 0.544 & 0.016 & 380 \\
\hline Opacity 4 & 50.128 & 51.000 & 376 \\
\hline Opacity 5 & 48.949 & 51.000 & 675 \\
\hline \multicolumn{4}{|c|}{ Panel B: Dividend implemented } \\
\hline Opacity 1 & 0.364 & 0.234 & 386 \\
\hline Opacity2 & 0.460 & 0.341 & 381 \\
\hline Opacity3 & 0.187 & 0.013 & 386 \\
\hline Opacity4 & 47.766 & 47.000 & 384 \\
\hline Opacity 5 & 44.836 & 42.500 & 675 \\
\hline \multicolumn{4}{|c|}{ Panel C: Year after dividend implementation } \\
\hline Opacityl & 0.348 & 0.206 & 326 \\
\hline Opacity2 & 0.408 & 0.305 & 325 \\
\hline Opacity 3 & 0.104 & 0.008 & 326 \\
\hline Opacity 4 & 44.242 & 44.000 & 322 \\
\hline Opacity 5 & 46.757 & 47.500 & 579 \\
\hline \multicolumn{4}{|c|}{ Panel D: Difference between $\mathrm{t}-1$ and $\mathrm{t}+1$} \\
\hline Opacityl & $\begin{array}{l}-0.0019 \\
(0.08)\end{array}$ & & \\
\hline Opacity2 & $\begin{array}{l}0.0531^{*} \\
(1.67)\end{array}$ & & \\
\hline Opacity 3 & $\begin{array}{l}0.4406^{* * *} \\
(2.95)\end{array}$ & & \\
\hline Opacity4 & $\begin{array}{l}5.8854 * * * \\
(4.36)\end{array}$ & & \\
\hline Opacity 5 & $\begin{array}{l}2.1915 \\
(1.39)\end{array}$ & & \\
\hline
\end{tabular}

Note. This table reports the opacity around changes in dividend policy. Panel A reports the opacity the year before a dividend is suspended. Panel B displays the opacity the year of a dividend suspension, and Panel $\mathrm{C}$ is the opacity the first year after a dividend is discontinued. Panel $\mathrm{D}$ reports the differences and t-statistics between the year prior and following a dividend suspension. T-statistics are reported in parentheses with $* * * * *$, and $*$ indicating significance at the $1 \%, 5 \%$ and $10 \%$ levels respectively. 


\section{Conclusion}

This paper provides theory and empirical results for a multiperiod explanation for why firms pay dividends. We develop a model that explains dividends in continuous time as a means of reducing agency cost. Shareholders will costlessly monitor managers when the firm is transparent. When firms are opaque, costless monitoring is not feasible. As a result dividends will be used to remove FCF and lower agency cost. Each period that the opaqueness of a firm can shift, and cost minimizing managers will reevaluate the dividend policy depending on the transparency of the firm.

Prior work focuses on single period decisions, where dividend policy is not evaluated after the initial dividend policy is set. In an economy where agency cost is a problem that is determined by firm opaqueness, dividends are an effective solution. The model provides two main testable implications. First, dividends are used by firms with high opaqueness, and second, dividend policy adjustments are the result of a change in the opacity of a firm.

We empirically test both of these implications. We find support that dividends are used by firms that have high opaqueness. Firms that pay dividends are ranked between one and seven percentiles higher in opaqueness than non-dividend paying firms. We also find some that changes in opaqueness are the result of dividend policy changes. When a firm suspends a dividend, we find that transparency is greater following the suspension of the dividend.

\section{References}

Bhattacharya, S. (1979). Imperfect Information, Dividend Policy, and The Bird in the Hand Fallacy. Bell Journal of Economics, 10, 259-270. http://dx.doi.org/10.2307/3003330

Dennis, D., \& Osobov, I. (2008). Why do firms pay dividends? International evidence on the determinants of dividend policy. Journal of Financial Economics, 89, 82-92.

Easterbrook, F. (1984). Two Agency-Cost Explanations of Dividends. American Economic Review, 74, 650-659.

Fuller, K., \& Goldstein, M. (2011). Do Dividends matter more in declining markets? Journal of Corporate Finance, 17, 457-473. http://dx.doi.org/10.1016/j.jcorpfin.2011.01.001

Jensen, M. C. (1986). Agency costs of free cash flow, corporate finance, and takeovers. American Economic Review, 76, 323-329.

John, K., \& Joseph, W. (1985). Dividends, Dilution, and Taxes: A Signaling Equilibrium. Journal of Finance, 40, 1053-1070. http://dx.doi.org/10.1111/j.1540-6261.1985.tb02363.x

Lang, L., \& Litzenberger, R. (1989). Dividend Announcements: Cash flow signaling vs. free cash flow hypothesis? Journal of Financial Economics, 24, 181-192. http://dx.doi.org/10.1016/0304-405X(89)90077-9

Lang, M., \& Maffett, M. (2011). Transparency and liquidity uncertainty in crisis periods. Journal of Accounting and Economics, 52(2), 101-125. http://dx.doi.org/10.1016/j.jacceco.2011.07.001

Lang, M., Lins, K. V., \& Maffett, M. (2012). Transparency, liquidity, and valuation: International evidence on when transparency matters most. Journal of Accounting Research, 50(3), 729-774. http://dx.doi.org/10.1111/j.1475-679X.2012.00442.x

Lintner, J. (1956). The Distribution of Incomes of Corporations Among Dividends, Retained Earnings and Taxes. American Economic Review, 46, 97-113.

Miller, M., \& Franco, M. (1961). Dividend Policy, Growth and the Valuation of Shares. Journal of Business, 34, 411-433. http://dx.doi.org/10.1086/294442

Miller, M., \& Kevin, R. (1985). Dividend Policy under Asymmetric Information. Journal of Finance, 40, 10311051. http://dx.doi.org/10.1111/j.1540-6261.1985.tb02362.x

Miller, M., \& Myron, S. (1982). Dividends and Taxes: Some Empirical Evidence. Journal of Political Economy, 90, 1118-1141. http://dx.doi.org/10.1086/261114

Ofer, A., \& Anjan, T. (1987). A Theory of Stock Price Responses to Alternative Corporate Cash Disbursement Methods: Stock Repurchases and Dividends. Journal of Finance, 42, 365-394. http://dx.doi.org/10.1111/j.1540-6261.1987.tb02572.x 


\section{Appendix A}

\section{Simple Numerical Example and Illustration of the Model}

Every period the shareholders of a firm are subject to agency cost. The manager gains utility from using firm resources in a way that does not increase the value of the firm. This could include, as other theoretical papers of suggested, elaborate offices, computers, and other luxury items paid by the owners of the firm. If the shareholders are able to observe the manager, then the manager will not be able to use as many firm resources for personal benefit.

For the purpose of this numerical example, assume that costs are standardized as an arbitrary unit. If the owners are able to observe what the manager is doing, then the agency cost will be 5 units. The shareholders can easily monitor the manager when the firm is transparent.

If the owners are not able to monitor what the manager is doing, then the agency cost will be 15 units. The manager knows that the firm is opaque and the owners are not able to see as clearly what the manager is doing. Numerical it is as follows:

$$
\text { Agency Cost }=A=\left\{\begin{array}{l}
5 \text { if the firm is transparent } \\
15 \text { if the firm is opaque }
\end{array}\right.
$$

The owners know that if the firm is transparent the manager will use firm resources in a manner that does not increase firm value. It is therefore advantageous for the owners to find a way to reduce the agency cost. Dividends (or repurchases) will remove excess cash from the owners. There is a cost to requiring a dividend or repurchase. If money is removed from the firm there will be an opportunity cost, given that some investment projects will be dismissed due to insufficient funds. There are also transaction costs associated with implementing a dividend. In our numerical example we suggest that the cost of implementing a dividend or repurchase is 6 units.

$$
\text { Opportunity cost }=D=4
$$

The dividend will reduce the opaque agency cost from 15. Assume that the agency cost will be 7 if a dividend is implemented. Notice that the dividend is only reduced to 7 , and not to 5 (The transparent firm agency cost). This is because dividends only reduce agency costs, not provide monitoring. If the cost of the dividend plus the new agency cost is less than the agency cost without a dividend, then it will be advantageous for shareholders to require a dividend. We refer to the new agency cost with a dividend as $A^{\prime}$. Numerically the total tradeoff is seen as,

$$
\text { Total Owner Cost }=A^{\prime}+D=7+4=11<15=\text { Agency cost of opaque firm without dividend }
$$

We can thus see it is beneficial for owners to require a dividend to lower agency cost. Even though the dividend is costly, it reduces agency cost.

One final note is that this cycle repeats every period in the economy. Since, as discussed in the model, the opaqueness can change from period to period depending on external (legal issues, environmental problems, competitors, etc.) and internal (new management, new project opportunities, etc.) shocks to the firm. An implication from the simple model is dividends will be more likely in firms that are opaque than firms that are transparent.

\section{Copyrights}

Copyright for this article is retained by the author(s), with first publication rights granted to the journal.

This is an open-access article distributed under the terms and conditions of the Creative Commons Attribution license (http://creativecommons.org/licenses/by/3.0/). 